\title{
Pró-Saúde and PET-Saúde in the Context of Reorientation Policy of Health Professions Training
}

\author{
Ana Maria Gomes dos Santos' ${ }^{1}$, Maria José Medeiros da Fonseca ${ }^{1}$, \\ Fernanda Fayane C. Belarmino ${ }^{1}$, Adriana Vitória dos Santos ${ }^{1}$, Fábia Barbosa de Andrade ${ }^{2}$ \\ ${ }^{1}$ City Health Department, Municipal Government, Santa Cruz, Brazil \\ ${ }^{2}$ Faculty of Health Sciences of Trairi (FACISA), Federal University of Rio Grande do Norte (UFRN), Santa Cruz, \\ Brazil \\ Email: ana_mariagsantos@hotmail.com,josymedeiros@ig.com.br, fernandabelarmino.cortez@bol.com.br, \\ adrianavsdossantos@yahoo.com.br,fabiabarbosabr@yahoo.com.br
}

Received 11 May 2015; accepted 28 December 2015; published 31 December 2015

Copyright (C 2015 by authors and Scientific Research Publishing Inc.

This work is licensed under the Creative Commons Attribution International License (CC BY). http://creativecommons.org/licenses/by/4.0/

(c) (i) Open Access

\section{Abstract}

The health education has been a topic discussed throughout Brazil, as the country is experiencing a period of expansion of higher education and it needs to give quality. So they were implanted two federal programs to allow that health students to approach their professional reality to make them capable of full mode. The paper aims to discuss the experience of the participating members of these programs for professional reorientation. The study is exploratory and descriptive conducted with participants of the programs in the city of Santa Cruz, Rio Grande do Norte, Brazil, in the year 2014. This study aims to present an experience report from the experience of the mentors in Reorientation National Program for Health Professional Training (Pró-Saúde), associated with the Labor Education Program for Health (PET-Saúde) at the Federal University of Rio Grande do Norte (UFRN)/Sciences College of Trairi (FACISA), with emphasis on the reorientation of professional practice, provided by integrating teaching-service and community as well as exchange of knowledge between tutors, mentors and students participating in the project, from the development of interdisciplinary activities, giving the opportunity to reflect on these actions and services offered based on the epidemiological analysis provided by research, intervening in this reality.

\section{Keywords}

Health Education, Education, Community, Learning, Students, Family Health 


\section{Introduction}

With the implementation of the Unified Health System (SUS) in the 80s, critical thinking in health is increasing, incorporating discussions about the social determination of the health-disease. With that a new paradigm in health care comes; the principles and guidelines break with the Flexnerian clinical paradigm and point to the need to print a new way of producing and distributing the actions and health services, i.e. to set up and define a new health care model [1]. Associated with this idea, we see the need for change of models of care and training of health professionals to work in line with the proposed model of health. Thus, the entire sector's public policy set requires adapting training for health work considering the social health needs and system management problems. In this sense, the teaching-service and academic institutions integration is also important, especially public universities, implementing research in the area and elaborating concepts of care practices in health.

The formalization of this change had its milestone with the introduction of the National Curriculum Guidelines (DCN) for undergraduate courses in health. All existing instruments guide the construction of the graduates profile through an academic and professional model in which attitudes, skills and content need the general, humane, critical and reflective education, responsible for operations in all health care levels, basing their conduct on the scientific and ethical rigor [2] [3].

Needing to approximate the undergraduate education in the country to Primary Care needs, new National Curriculum Guidelines (DCN) were proposed in Resolution CNE/CES no 4, 2001. According to the DCN, the development curriculum axis should be the health needs of the population, in order to promote interaction between education, service and community, especially Unified Health System (SUS) services. In 2001, the National Curriculum Guidelines were formulated for undergraduate courses in Medicine, Nursing and Nutrition, about guidelines for the preparation of curriculum by higher education institutions, easing the training offered to students, adapting it to the current health system in the country [4].

This challenge has generated different strategies for the implementation of this new model in services. It is possible to mention the Family Health Program (PSF), later known as the Family Health Strategy (ESF), among others. The main idea was to reorganize the practices, by strengthening primary health care in the country, based on health promotion, disease prevention, treatment and rehabilitation [5].

Considering the growing reality of higher education in Brazil, they were created by the federal government's two programs entitled: Reorientation National Program for Professional Training in Health (Pró-Saúde) and Education Program for Working for Health (PET-Saúde) to look for integrate knowledge of teaching, research and extension through the teaching-service-community trilogy.

Pró-Saúde wants to syntonize health education with social needs, considering the historical, cultural and economic dimensions of the population [6]. It encourages for the study object stops being the focus on the disease and starts being person's care. Pro-Health is enabling the development of academic-professional and pedagogical training integration, enabling professionals who perform activities in the area of primary health care, can guide graduate students in the public health service, and is the main practical scenario [7].

The intention was to minimize the gap between theory built during the academic education and the real needs of life and health of the population, to stimulate the formation of critical and reflective professionals. These workers should be able to work in an interdisciplinary way, committed to their technical and social responsibilities and to improve the quality of higher education [8] [9].

Through the Secretary of Labor Management and Health Education, along with the Ministry of Education, through the Department of Higher Education, the Ministry of Health created the Labor Education Program Health (PET-Saúde), established by ministerial decree 421, of March 3, 2010 to complement Pró-Saúde acting.

PET-Saúde is characterized as a Pró-Saúde strategy to encourage training tutorial learning groups in priority areas for SUS, entering students in health graduations while in service. This project encourages the integration of education, service and community, aimed at interaction with the everyday to professionals training to aware the needs of health services. It also seeks to stimulate the ongoing training of workers already in the labor area, making them co-producers of knowledge and practices for the different demands of the population assisted by the Brazilian health system [10].

The interdisciplinary is one of the elements, or one of the ways that enables approaches to an Integral Health Care practice. Integrality must be articulated to the need of modifying a fragmented and disarticulated way of acting in health. To modify this disarticulated and individualistic practice, ESF has emerged as a SUS action tool, possibly effective to operationalize the health practice with an interdisciplinary view. These interdisciplinary practices in teaching are essential to the health education [11].

In this way, the interdisciplinary dynamic program tends to favor the understanding of a new knowledge for 
the production of other practices that intend the articulation of knowledge with the needs of individuals. Interdisciplinarity is a knowledge transposition action on the exterior to the internal structures of the individual, constituting the knowledge [12].

As for the structure of the Pró-Saúde and PET-Saúde in late 2011, the Secretary of Labor Management and Health Education elaborated a notice Pró-Saúde and PET-Saúde. The notice encouraged the proposals that addressed the policies and priorities of the Ministry of Health, such as Cegonha Network, Urgency and Emergency Network, Psychosocial Care Network, Prevention Actions and Diagnosis Qualification and Treatment of Colon and Breast Cancer, Plan to Combat Chronic Non-communicable Disease. The objective was to mobilize higher education institutions in the country, together with municipal and state departments of Health and community participation, with most teaching-service integration, centrality of health in the production and humanized care at the undergraduate training of Health area professions [13].

Pró-Saúde, articulated to PET-Saúde, is developed in the Health Care networks, with participation of teachers, students, Health service staff and SUS users. Currently, there are 120 Pró-Saúde projects in process articulated to PET-Saúde with the development of 415 tutorial groups. Considering the notices from Pró-Saúde by 2011, there were 379 graduate courses on the Program. From the notice that integrated Pró-Saúde/PET-Saúde programs in 2012, there were 389 new courses involved, totaling 709 undergraduate courses in the Healthcare area [14].

On March 15, 2012, at the 4th extraordinary meeting of the Inter Regional Commission of the 5th Health Region, Pró-Saúde Project was approved, articulated to PET-Saúde, from Health Sciences College of Trairi/UFRN (FACISA), established in Santa Cruz/RN, in line with the Notice Number 24/2011, of the Ministry of Health, selected, respectively, with two groups: Cegonha Network and Psychosocial Network to act together with health institutions. Pró-Saúde and PET-Saúde from FACISA develop articulated works in nursing, nutrition and physiotherapy courses, which points to a broad and diverse field of knowledge. This interaction tends to allow greater interaction between teachers, professionals and students with a view to generate a more critical and reflexive formation in favor of the user provided care quality.

Thus, these programs have enabled experiences that broaden the view of teachers, students and the service professionals about the care to the individual who gets sick in the context of its existence, contributing to the listening permeated by doubt, charms and findings of unpredictable, qualifying Healthcare that values the relationship between humans.

The report aims to contribute to the demonstration of the actions proposed by Pró-Saúde and PET-Saúde, Cegonha Network from FACISA/UFRN and for understanding the working dynamic that has generated reflective processes in the different actors of this process.

\section{Experience Report}

This is an experience report of the actions developed by the Pró-Saúde and PET-Saúde, Cegonha Network of FACISA/UFRN, focusing on the importance of participation in this project for health training, through the nursing, nutrition and physiotherapy courses in the context of the reorientation of political training of health professions. The guiding principle of this report was the interdisciplinary activities developed by the group.

The actions developed by this group are of great importance to students' education, because when seeking to work with integrality and teaching and service articulation, theory and practice approximate each other and promote reflections of those involved in this dynamic.

In Pró-Saúde/PET-Saúde Cegonha Network of FACISA/UFRN implementation, a meeting between tutors, mentors and nursing, nursing and physiotherapy students was performed as initial activity where the project proposal was exposed (teaching-service-community integration) and distribution of students to work in the municipal health service (Family Health Strategy, Ana Bezerra University Hospital and V Regional Health). The inclusion of students in the initial period took place in order to know the routine of their services and identify from that experience the critical nodes related to Cegonha Network policy. This first step generated integration between groups, as shown in Figure 1.

This dynamic favored the presentation of the main necessities of the group, contributing to outline the type of actions that would be developed in the following steps. These activities took place with weekly interdisciplinary meetings with the participation of different students from Pró-Saúde/PET-Saúde Cegonha Network of FACISA, where there were scholarship students and volunteers, tutors and mentors of nursing, nutrition and physiotherapy courses. 


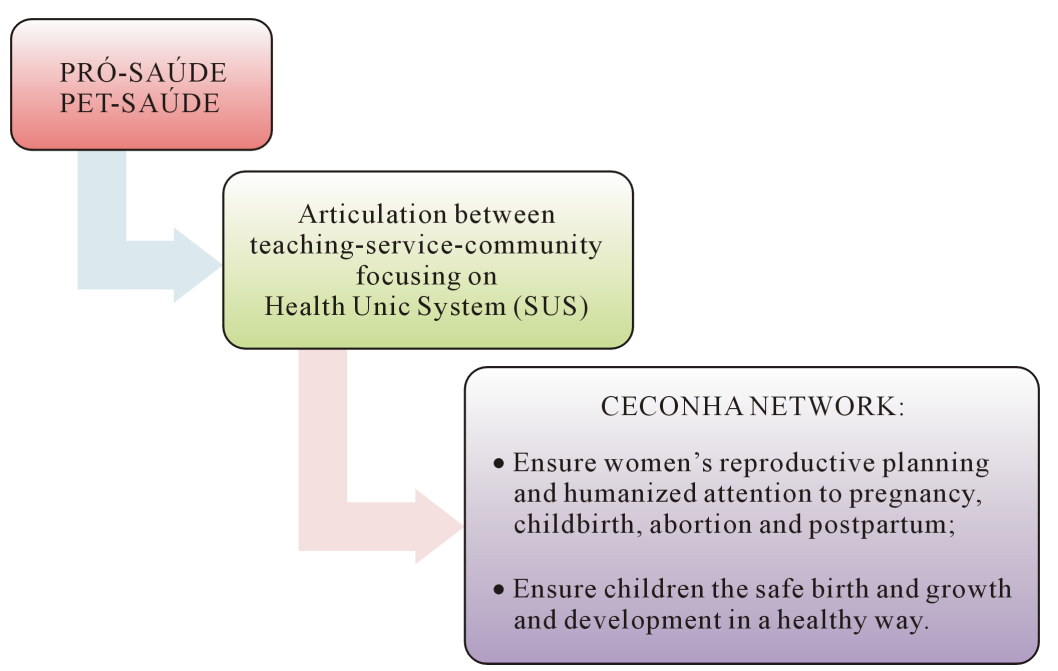

Figure 1. Pró-Saúde/PET-Saúde: interventions in Cegonha network.

At the meetings were worked several themes inherent in the teaching and learning of the courses participating in the program. At such times, the knowledge of the group members towards reflections and practices to meet the social needs and focus specific attention of institutional design were considered and articulated.

Each monthly meeting of all groups, according to the skills of their training in health, they were responsible for the presentation of activities in health services with the discussion of their process partners. Such action was characterized as the construction of a space for the exchange of knowledge and favored reflections on interdisciplinarity. There were weekly meetings involving tutors, mentors and scholarship students and volunteers of nursing, nutrition and physiotherapy courses, specifically with regard to the activities promoted by Pró-Saúde/ PET-Saúde Cegonha Network.

There was knowledge sharing during the training, promoting a close contextualized relationship between theory and practice. The integrality guides the training for a fairer, more ethical and human professional, regardless of the labor market [15].

Based on the reflections of the meetings, the Pró-Saúde/PET-Saúde Cegonha Network group adopted the workshops as a pedagogical tool for interaction with community actors as well as the creation of booklets within the Cegonha Network proposal (Booklet of Newborns Care and Booklet of Umbilical Stump Care). This strategy articulates dynamics as do-it-yourself, group activities, videos, music, creation of the group of pregnant women in basic health units among others, favoring the development of reflective and critical thinking and reconstruction of knowledge, based on the context in which they live. In this sense, the exchange of knowledge between the actors involved was subsidized by a new approach, which sought to empower these people on issues related to life and health needs. No one educates anyone, no one educates himself, and men educate each other, mediated by the world [16].

These actions are being developed in the project. Thus, analyzing the continuity of the program, since its academic implementation, it is possible to characterize it as a valuable strategy of interaction, teaching-servicecommunity whether students, whether tutors, mentors and other segments of the population.

\section{Pro-Saúde/PET-Saúde Practice, FACISA Cegonha Network/UFRN: Some Considerations}

In the teaching proposal, transforming the health training process, Pró-Saúde/PET-Saúde Cegonha Network of FACISA/UFRN tends to contribute to build critical and reflective knowledge of knowledge and practices. This is because due to their action strategies there are values present in the university for the experience of students, professionals and service for the benefit of the community.

For transformation of the organization services and training processes, it is necessary the work together between the health system and the training institutions, since the integrality care involves understanding the expansion of the clinic, the knowledge of reality, the work team, intersectoral and humanization action [1]. Thus, the student expands and enriches their view on the local socio-political reality, interacting with society and de- 
veloping social thinking about their future professional practice [17].

It is necessary this relationship is established with the university, so that the interaction favors the co-production of critical and reflective workers as well as the strengthening of policy reorientation of health professions. This promotion developed in the educational sphere promotes the identification of its own values and overcoming limits found in the training process of individuals [18].

However, in view of the educational proposal of Pró-Saúde and PET-Saúde, approaching and integrating the actors involved with the reality of services, it was possible to elaborate the research of the production of knowledge through teaching-service-community integration.

This construction took place in the context of the plans developed together with strategic areas of the National Primary Health Care Policy. Therefore, several readings of articles and organizing short courses related to the theme were carried out, as well as discussions involving aspects related to health research. In addition, interdisciplinary meetings, discussions among peers and encouraging the (re)evaluation of teaching, of research and social practice served as a stimulus for publications and participation of tutors, mentors and students in academic events.

Both in graduation and in the research and extension projects, it is understood that the integration between teaching and service should be combined, including the academic and health services in order to meet the needs and to improve health care to the population through better training of the professionals [19].

Therefore, thinking about the integration of teaching and service is in the basic axes of any university, especially by linking education, research and extension, increasing the research as a means to discover and transform the everyday. The permanence in practical field allowed the students new point of view, so far overshadowed by the restricted environment of the classroom, and enabled those involved in the project a concrete approach to the reality, allowing diversification in learning scenarios. In addition, it instigated social responsibility, favoring rethink the role of the academy in meetings with the community searching for their social rights.

The meetings involving representatives of nursing, nutrition and physiotherapy courses were constituted as essential moments for the mediation of a series of interdisciplinary discussions on various topics. With the importance of interdisciplinarity as a tool for integration between the various professional categories in the reorientation of policy, this dynamic has opportunities for research, presentation of problems and analysis of socio-epidemiological profiles and actions performed by the groups, creating new looks for individual and collective practices outlined by the teamwork.

The interdisciplinary work occurs through approach about phenomenon that influence the health of the population, aiming to achieve more effective programs and services offered to the population [13].

In entanglement of interdisciplinary knowledge, the different conceptions are listed, facilitating the understanding of the ideals of each academic course and the actions generated by the professionals' service. All are urged to reflection originated at each meeting, allowing the improvement of academic training, service and health practice. The meetings and activities undertaken during project activities were a tool in the qualification in service of health professionals, helping to build another point of view at the daily practices and the strengthening of Primary Care in Cegonha Network policy.

\section{Final Considerations}

The Continuing Health Education (EPS) has been consolidated as a political-pedagogical strategy necessary for reorganization of work processes, services and health practices, paradigm changes, with emphasis on the integrality of care, giving a wide health point of view for health workers, enhancement of intersectoral and multidiscilinar work as well as the construction of thoughtful and reflective subjects.

In this way, by deepening the partnership between the Ministries of Health and Education, through the reorientation of vocational training policy, the relationship between academy and community services have been strengthening, redefining their acting roles, and the organization of this policy in the collegiate, through the Committee of Teaching and Service Integration (CIES), Health Boards and Inter Commissions, building the proposal of Pró-Saúde and PET-Saúde within municipal and state health policies.

In this sense, the interdisciplinary approach has been highlighted, both in the context of the reorientation of political training of health professionals advocated in Pró-Saúde, as in the practice of the health team services, based on the precepts of the care model, in order to ensure an integral approach of the health-disease process, to provide changes in the provision of services to the community. 


\section{Conclusion}

It can be concluded that, recognizing the success of actions taken by Pró-Saúde and PET-Saúde Cegonha Network of FACISA/UFRN through interdisciplinary research and education, service and community integration, provided the activities of these programs, favoring the development of new practices and community satisfaction. In this sense, many teaching moments, services and community integration experienced by tutors, mentors and students of this project tended to encourage the constant updating of professionals with a view to forming them with appropriate profile to the needs and policies of the country's health.

\section{References}

[1] Freitas, P.H., Colomé, J.S., Carpes, A.D. and Beck, C.L.C. (2013) Pet-Health Impact of the Training of Students in the Health Area. Escola Anna Nery, 17, 496-504. http://www.scielo.br/pdf/ean/v17n3/1414-8145-ean-17-03-0496.pdf

[2] Ministry of Education, Brazil (2011) CNE/CES no. 274/2011 of 6 July 2011. Statement on the Revision of the Text of the National Curriculum Guidelines for Undergraduate Courses in Physical Education. http://portal.mec.gov.br/cne/arquivos/pdf/CES0492.pdf

[3] Ministry of Education. Resolution, Brazil (2011) CNE/CES \# 5 of 15 March 2011. It Establishes the National Curriculum Guidelines for Undergraduate Courses in Psychology, Establishing Standards for the Complementary Education Program for Formation of Psychology Teachers. http://portal.mec.gov.br/cne/arquivos/pdf/CES05.pdf

[4] Ministry of Education, Brazil (2001) CNE/CES no. 12001 of 7 August 2001. National Curriculum Guidelines for Undergraduate Nursing, Medicine and Nutrition. http://portal.mec.gov.br/component/content/article?id=12991

[5] Ministry of Health, Brazil (2008) SUS Indicators Panel: Family Health Theme. Ministry of Health, Brasília.

[6] Ministry of Education, Brazil (2009) Secretary of Labor Management and Health Education Department of Health Education Management National Policy of Permanent Education in Health. The Ministry of Health, Brasilia.

[7] Ferraz, L. (2012) The Educational Program for Health Work (PET-Saúde) and Its Dialogue with the Pró-Saúde Program Based on Research: A Case Report. Revista Brasileira de Educação Médica, 36, 166-171. http://www.scielo.br/pdf/rbem/v36n1s1/v36n1s1a23.pdf http://dx.doi.org/10.1590/S0100-55022012000200023

[8] Brazil Ministry of Health. Ministry of Education. Reorientation National Programme of Vocational Training in Health. Pro-Health: Objectives, Implementation and Potential Development. Brasília, DF, 210.

[9] Brazil (2010) Ministry of Health. Health Portal. http://bvsms.saude.gov.br/bvs/publicacoes/programa_nacional_reorientacao_profissional_saude.pdf

[10] Sousa, M.A., Caixeta, J.E. and Santos, P.F. (2011) Construction of Solidarity Identities: Commitment of Higher Education. Rev Facsenac, 2, 1-18. http://www.unl.edu.ar/iberoextension/dvd/archivos/ponencias/mesa3/construcao-de-identidades-pr.pdf

[11] Bishop, E.P.F., Tavares, C.H.F. and Tomaz, J.M.T. (2014) Interdisciplinarity in Health Education: The Look of the Preceptor in the Family Health. Interface Communication Health and Education. http://www.scielo.br/pdf/icse/v18n49/1807-5762-icse-1807-576220130158.pdf

[12] Brazil (2013) Ministry of Health Secretariat Management of Labor and Health Education: SGTES. http://bvsms.saude.gov.br/bvs/folder/pro_saude_pet_saude.pdf

[13] Ferreira, E.F., Vargas, A.M., Amaral, J.H.L., Vasconcelos, M. and Mattos, F.F. (2006) Crossing the Path of Completeness: A Experience of the UFMG Dentistry Course. In: Pinheiro, R., Ceccim, R.B., Mattos, R.A., Orgs., EnsinoWork-Citi- zenship: New Brands to Teach Comprehensiveness in SUS, UERJ, IMS: ABRASCO, Rio de Janeiro, 85-92.

[14] Freire, P. (2002) Pedagogy of the Oppressed. Paz e Terra, Rio de Janeiro.

[15] Ceccim, R.B. and Feuerwerker, L.M. (2004) The Quad Training for Health Area: Education, Management, Care and Social Control. Physis, 14, 41-65.

[16] Loch-Neckel, G., Seemann, G., Eidt, H.B., Rabuske, M.M. and Crepaldi, M.A. (2009) Challenges to an Interdisciplinary Action in Basic Care: Implications Related to Composition of Family Health Teams. Ciência \& Saúde Coletiva, 14, 1463-1472. http://dx.doi.org/10.1590/S1413-81232009000800019

[17] Fields, F.E., Brenelli, S.L., Wolf, L.C. and Haddad, A.E. (2009) The SUS as School: Social Responsibility with the Health Care of the Population and the Learning of Future Health Professionals. Revista Brasileira de Educação Médica, 33, 513-514. http://www.scielo.br/pdf/rbem/v33n4/v33n4a01.pdf

[18] Brazil. Ministry of Health. Http://prosaude.org/not/prosaude-maio2009/proSaude.pdf

[19] Sousa, I.F., Bogo, D. and Bastos, P.R.H.O. (2013) Interdisciplinary Training for Operations in the Health System: Overview of Articles Published in Brazil. Magazine Saúde.Com, 9, 49-59.

http://www.uesb.br/revista/rsc/v9/v9n2a06.pdf 